\title{
Pemetaan Fenomena Urban Heat Island Di Kota Kendari Dengan Menggunakan Citra Resolusi Menengah
}

\author{
Fatimah Wardhana $^{1)}$, Golok Jaya ${ }^{2)}$, Fitra Saleh ${ }^{2)}$, Jufri Karim ${ }^{2)}$ \\ 1) Jurusan Geografi Universitas Halu Oleo \\ 2) Geografi Universitas Halu Oleo \\ Email:fatimah.wrdn@gmail.com
}

\begin{abstract}
Abstrak: Fenomena Urban Heat Island dapat dipetakan dengan parameter Suhu Permukaan Tanah (SPT) dan indeks kerapatan vegetasi (NDVI). Penelitian ini bertujuan untuk menganalisis Urban Heat Island di Kota Kendari menggunakan Landsat 8 OLI/TIRS dan menganalisis kondisi eksisting sebaran fenomena Urban Heat Island di Kota Kendari. Proses dilakukan dengan mengolah data citra Landsat 8 OLI/TIRS perekaman 30 Agustus 2017. Analisis dilakukan dengan menggunakan algoritma Syariz untuk penentuan SPT yang kemudian dikorelasikan dengan nilai NDVI yang dihasilkan dari kaliberasi band 4 dan band 5 pada citra Landsat 8 OLI/TIRS. Hasil penelitian ini menunjukkan suhu permukaan tanah di kota Kendari berkisar antara $15,27^{\circ} \mathrm{C}$ hingga $33,34^{\circ} \mathrm{C}$. Dimana suhu $15^{\circ} \mathrm{C}$ hingga $22^{\circ} \mathrm{C}$ adalah suhu daerah yang tidak terdeteksi atau tertutup awan. Persebaran suhu didominasi suhu antara $23-27^{\circ} \mathrm{C}$ dengan luas $21.492,46 \mathrm{Ha}$ atau $81,02 \%$ dari luas wilayah, dengan wilayah yang teridentifikasi sebagaui daerah UHI dengan suhu diantara $28-33^{\circ} \mathrm{C}$ seluas $2.968,57 \mathrm{Ha}$ atau $11,01 \%$ dari total luas wilayah Kota Kendari. Nilai korelasi antara SPT dan NDVI berada pada angka -0,66 yang berarti bahwa tingkat kerapatan vegetasi berbanding terbalik dengnan nilai suhu permukaan tanah atau semakin rendah indeks kerapatan vegetasinya, maka semakin tinggi suhu permukaan tanahnya.
\end{abstract}

\section{Kata kunci: Urban Heat Island, suhu permukaan tanah, Landsat 8, NDVI}

Abstract: The Urban Heat Island phenomenon can be mapped with the parameters of Land Surface Temperature (LST) and the Normalized Difference Vegetation Index (NDVI). This study aims to analyze Urban Heat Island in Kendari City using Landsat 8 OLI / TIRS and analyze the existing conditions of the distribution of the Urban Heat Island phenomenon in Kendari City. The process is done by processing Landsat 8 OLI / TIRS image recording data on August 30, 2017. The analysis carried out using the Syariz algorithm to determine LST which is then correlated with NDVI values resulting from band 4 and band 5 in Landsat 8 OLI / TIRS images. The results showed that the land surface temperature in Kendari ranged from $15.27^{\circ} \mathrm{C}$ to $33.34^{\circ} \mathrm{C}$. The 15 to $22^{\circ} \mathrm{C}$ is the temperature of the clouded or undetected area. The temperature distribution is dominated by temperatures between $23-27^{\circ} \mathrm{C}$ with an area of $21,492.46 \mathrm{Ha}$ or $81.02 \%$ of the total area, with areas identified as UHI are the areas with temperatures between $28-33^{\circ} \mathrm{C}$ with an area of $2,968.57 \mathrm{Ha}$ or $11.01 \%$ of the total area of Kendari City. The correlation value between SPT and NDVI is at -0.66 , which means that the vegetation density level is inversely proportional to the value of the land surface temperature value or the lower the vegetation index value, the higher the surface temperature of the land.

Keywords: Urban Heat Island, land surface temperature, Landsat 8, NDVI 


\section{PENDAHULUAN}

Perubahan iklim telah menjadi perhatian utama negara-negara di seluruh dunia saat ini. Berdasarkan laporan dari Intergovernmental Panel on Climate Change (IPCC) pada tahun 2007 menemukan bahwa rata-rata peningkatan suhu permukaan bumi mencapai $2-3^{\circ} \mathrm{C}$ setiap tahun. Kenaikan suhu permukaan tersebut juga dibarengi dengan naiknya muka air laut, hingga memicu terjadinya banyak bencana alam seperti banjir di perkotaan maupun terjadinya fenomena Urban Heat Island (UHI).

Fenomena UHI ditandai dengan terjadinya peningkatan suhu di kota, dimana pusat kota mempunyai suhu lebih tinggi dibandingkan dengan daerah disekitarnya. Kota-kota yang banyak mengalami UHI adalah kota-kota yang menjadi tujuan urbanisasi. Hal ini menyebabkan semakin hari jumlah bangunan di perkotaan semakin bertambah. Selanjutnya, menyebabkan terbentuknya fenomena UHI di kawasan tersebut. Fenomena UHI pertama kali ditemukan oleh Luke Howard pada tahun 1818 (Sham, 1980; dalam Tursilowati 2012).

Kota Kendari sebagai salah satu pusat urbanisasi di wilayah Sulawesi Tenggara merupakan salah satu kota pesisir di Indonesia yang cenderung mengalami peningkatan suhu udara setiap tahunnya. Pada tahun 2010, suhu udara rata-rata di Kota Kendari tercatat sebesar $24^{\circ} \mathrm{C}$, dan pada tahun 2016 sebesar $28^{\circ} \mathrm{C}$ (Santi, 2017). Hal ini menjadikan Kota Kendari sebagai salah satu Kota di Indonesia dengan suhu udara yang cukup panas.

Penelitian ini bertujuan untuk menganalisis UHI di Kota kendari dengan menggunakan Landsat 8 dan untuk menganalisis kondisi eksisting sebaran fenomena UHI di Kota kendari.

\section{METODE PENELITIAN}

\subsection{Lokasi Penelitian}

34 --- April
Kota kendari yang berada di antara 3'54'30" - 4'3'11" Lintang Selatan dan $122^{\circ} 23^{\prime}$ - $122^{\circ} 39^{\prime}$ Bujur Timur menjadi lokasi penelitian ini dilakukan (Gambar 1).

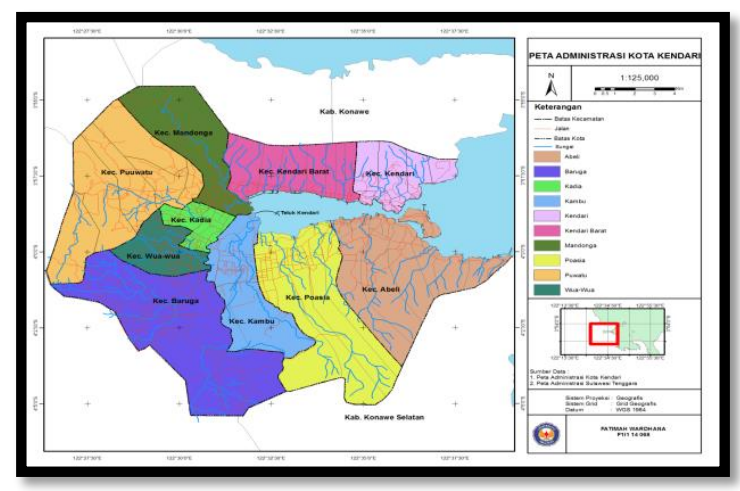

Gambar 1. Peta Lokasi Penelitian

\subsection{Analisis Penggunaan Lahan}

Analisis penggunaan lahan akan menghasilkan peta penggunaan lahan. Peta penggunaan lahan berasal dari interpetasi manual dan digitasi citra Google Earth. Pengkelasan penggunaan lahan pada penelitian ini disesuaikan dengan kelas penggunaan lahan pada RTRW Kota Kendari. Maka kelas penggunaan lahan dibagi atas, permukiman kerapatan tinggi, sedang dan rendah, vegetasi kerapatan tinggi, sedang dan rendah, lahan kosong, perdagangan dan jasa, tambak, Ruang Terbuka Hijau, kawasan pendidikan, dan industri.

Hasil dari interpetasi kemudian disesuaikan dengan hasil uji lapangan. Proses ini dinamakan re-interpretasi yaitu proses interpretasi kembali yang bertujuan untuk membenarkan hasil interpretasi yang sesuai dengan keadaan di lapangan.

\subsection{Analisis Normalized Difference Vegetation Indeks (NDVI)}

Analisis NDVI digunakan untuk melihat keterkaitan suhu permukaan daratan dengan tingkat kerapatan vegetasi, sehingga menghasilkan peta indeks kerapatan vegetasi. Peta NDVI pada penelitian ini menggunakan citra Landsat 8 OLI/TIRS. Adapun Rumus aritmatik untuk menentukan indeks vegetasi menurut Lillesand dan Kiefer (2000) adalah sebagai 
berikut:

$N D V I=(\rho N I R-\rho R E D) /(\rho N I R+\rho R E D)$

Keterangan:

NDVI : Nilai BV dari Normalized Difference Vegetation Index

$\rho N I R$ : (Near Infra Red) Nilai band spektral inframerah dekat

$\rho$ RED : Nilai band spektral merah

\subsection{Analisis Sebaran Suhu Permukaan Tanah}

Sebelum melakukan perhitungan nilai Suhu Permukaan Tanah (SPT) untuk mengidentifikasi UHI, citra Landsat 8 yang sudah terkoreksi geometrik harus diolah lagi menggunakan software pengolahan citra. Point-point teoritis mengenai algoritma pengolahan tersebut adalah sebagai berikut:

a. Digital Number ke Spektral Radian

Berikut adalah persamaan untuk mengkonversi nilai Digital Number (DN) ke spektral radian:

$L \lambda=M L^{*} Q c a l+A L$

Keterangan:

$\mathrm{L} \lambda=$ Spektral Radian

ML $=$ Faktor Skala

Qcal = Digital Number

$\mathrm{AL} \quad=$ Faktor Penambah

b. Spektral Radian ke Kelvin

Berikut adalah persamaan untuk mengkonversi nilai spektral radian ke satuan Kelvin :

$T=\frac{K 2}{\ln \left(\frac{K 1}{L \lambda}+1\right)}-273$

di mana :

$\mathrm{T}=$ Suhu (Celcius)

$\mathrm{L} \lambda=$ Nilai Radian pada band thermal

$\mathrm{K} 1, \mathrm{~K} 2=$ Ketetapan (konstanta)

\subsection{Analisis Korelasi}

Suhu permukaan daratan hasil pengolahan citra dianalaisis korelasinya dengan suhu permukaan daratan di lapangan. Persamaan untuk analisis korelasi menurut Sugiyono (2007) adalah $r=\frac{n \Sigma X Y-(\Sigma X)(\Sigma Y)}{\left.\sqrt{n \Sigma X^{2}-\Sigma X^{2}\left(n \Sigma Y^{2}\right.}-\Sigma Y^{2}\right)}$

Keterangan:

$\mathrm{r} \quad=$ Korelasi

$\mathrm{X}=$ Suhu Lapangan

$\mathrm{Y}=$ Suhu Hasil Pengolahan Citra

$\mathrm{n} \quad=$ Jumlah Data

Untuk dapat memberikan penafsiran dalam koefisien korelasi yang ditemukan tersebut besar atau kecil, maka dapat berpedoman pada (Tabel 1).

Tabel 1. Penafsiran Koefisien Korelasi

\begin{tabular}{cc}
\hline Interfal Koefisien & Tingkat Hubungan \\
\hline $0-0,19$ & Sangat Rendah \\
\hline $0,2-0,39$ & Rendah \\
\hline $0,4-0,59$ & Sedang \\
\hline $0,6-0,79$ & Kuat \\
\hline $0,8-1$ & Sangat Kuat \\
\hline
\end{tabular}

\section{HASIL DAN PEMBAHASAN}

\subsection{InterpretasiPenggunaan Lahan}

Interpretasi penggunaan lahan dan pembuatan peta penggunaan lahan pada penelitian ini dilakukan dengan digitasi citra Google Earth Kota Kendari tahun 2017. Total luas lahan di Kota Kendari sendiri adalah sejumlah 26,979,14 Ha yang kemudian dibagi ke dalam beberapa kelas yaitu permukiman kerapatan tinggi, sedang, rendah, vegetasi kerapatan tinggi, sedang, rendah, ruang terbuka hijau, kawasan pendidikan, lahan kosong, tambak, industri serta perdagangan dan jasa dengan presentasi dan sebaran masing-masing penggunaan lahan seperti (Gambar 2 dan 3).

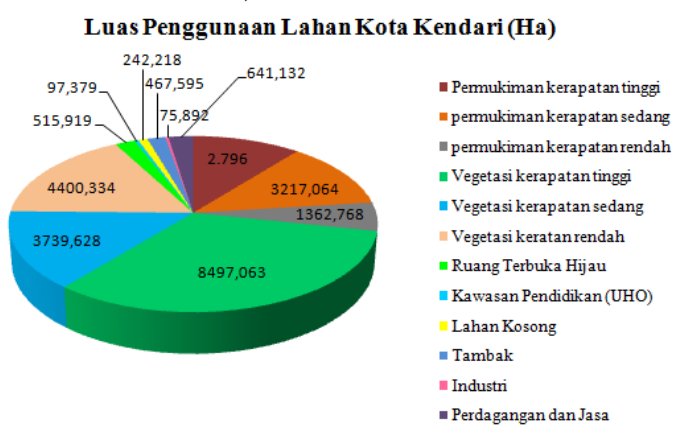

Gambar 2. Grafik Penggunaan Lahan Kota Kendari 


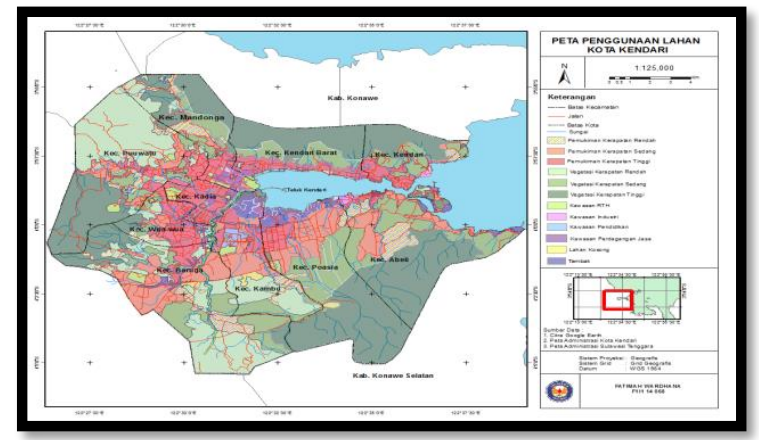

Gambar 3. Peta Penggunaan Lahan Kota Kendari

\subsection{Normalized Difference Vegetation Indeks (NDVI)}

Nilai NDVI berkisar antara $-1,0$ sampai 1,0, akan tetapi nilai-nilai yang kurang dari nol biasanya tidak memiliki makna ekologis. Kisaran tingkat kerapatan NDVI dapat dilihat pada tabel 2.

Tabel 2. Tingkat Kisaran Kerapatan

\begin{tabular}{cc}
\multicolumn{2}{c}{ Vegetasi } \\
\hline Kisaran NDVI & Tingkat Kerapatan \\
\hline$-1-0,32$ & Jarang \\
\hline $0,33-0,42$ & Sedang \\
\hline $0,43-1$ & Tinggi \\
\hline
\end{tabular}

Sumber: Departemen Kehutanan (2003)

Hasil kalibrasi band 4 dan 5 pada

citra Landsat 8 OLI/TIRS tingkat kerapatan vegetasi yang didapatkan untuk wilayah Kota Kendari berkisar antara $0,125 \mathrm{~s} / \mathrm{d}$ 0.624. Sebaran kerapatan vegetasi tersebut dapat dilihat pada (Gambar 4) dimana wilayah dengan kerapatan vegetasi yang tinggi berwarna hijau, sedang berwarna kuning dan jarang berwarna merah.

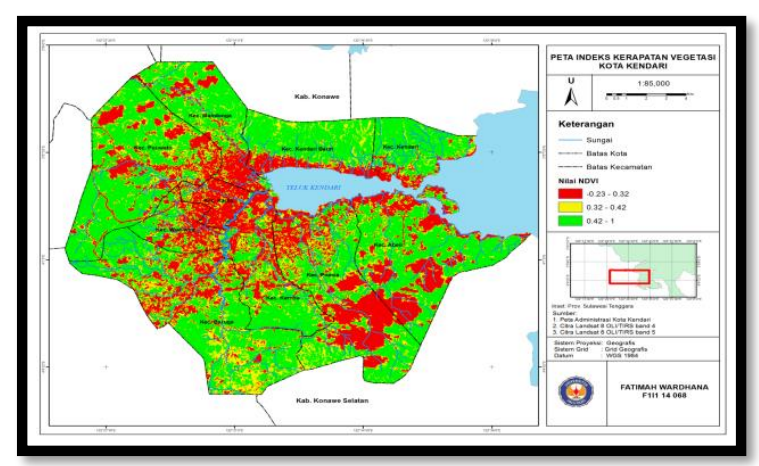

Gambar 4. Peta Indeks Kerapatan Vegetasi Kota Kendari

\subsection{Sebaran Suhu Permukaan Daratan}

Data hasil pengolahan citra Landsat 8 OLI/TIRS band 10 perekaman tanggal 30 Agustus 2017 suhu dominan yang terlihat berkisar antara $23-33{ }^{\circ} \mathrm{C}$ yang tersebar di seluruh kecamatan yang ada di Kota Kendari. Terlihat gradasi warna dari merah ke kuning. Semakin merah menunjukkan suhu permukaan daratan yang semakin tinggi, sedangkan semakin bewarna kuning kehijauan menunjukkan suhu permukaan daratan yang semakin rendah. Gambaran sebaran suhu permukaan daratan dengan band 10 dapat dilihat pada (Gambar 5).

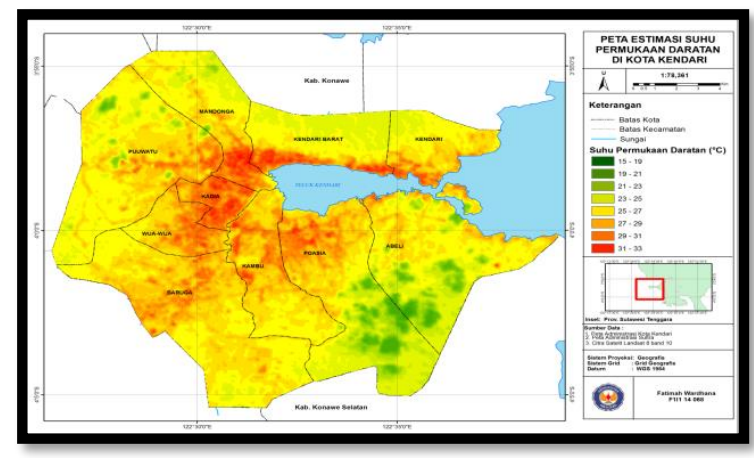

Gambar 5. Peta Sebaran Suhu Permukaan daratan Band 10

Data hasil pengolahan citra Landsat 8 OLI/TIRS band 11 perekaman tanggal 14 September 2017, hasil yang didapatkan berbeda dengan suhu yang didapatkan pada band 10. Pada band 11 suhu dominan yang terlihat berkisar antara $20-28{ }^{\circ} \mathrm{C}$ yang tersebar di seluruh kecamatan yang ada di Kota Kendari. Terlihat gradasi warna dari merah ke kuning. Semakin merah menunjukkan suhu permukaan daratan yang semakin tinggi, sedangkan semakin bewarna kuning kehijauan menunjukkan suhu permukaan daratan yang semakin rendah. Gambaran sebaran suhu permukaan daratan dengan band 11 dapat dilihat pada (Gambar 6). 


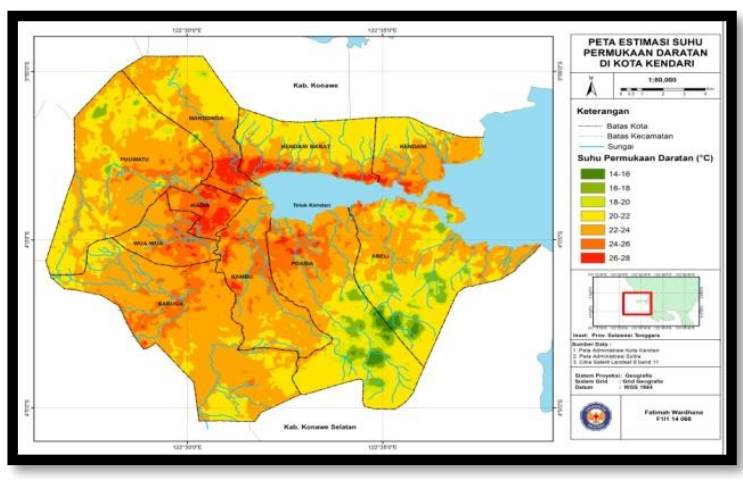

Gambar 6. Peta Sebaran Suhu Permukaan daratan Band 11

\subsection{Uji Korelasi}

Nilai suhu permukaan daratan hasil ekstraksi pada band 10 citra landsat 8 OLI/TIRS, tidak memiliki kesamaan dengan suhu yang didapatkan di lapangan. Suhu di lapangan rata-rata lebih tinggi 3 hingga 4 derajat Celcius dibandingkan suhu pada citra. Sedangkan suhu permukaan daratan yang dihasilkan dari ekstrasi band 11 menunjukkan perbedaan yang sangat signifikan dengan suhu yang didapatkan pada pengukuran suhu di lapangan. Besar perbedaan suhu bahkan mencapai 8 derajat Celcius.

Penentuan kebenaran suhu permukaan daratan hasil pengolahan dengan suhu permukaan dilapangan adalah dengan analisis korelasi. Dari analisis korelasi bisa diketahui apakah suhu permukaan daratan hasil pengolahan citra mempunyai hubungan dengan kondisi dilapangan. Oleh karena itu dilakukan uji korelasi pada suhu hasil ekstrasi kedua band, baik band 10 maupun band 11 .

Berdasarkan 24 titik sampel yang diuji korelasinya antara suhu permukaan daratan hasil pengolahan citra pada band 10 dan suhu dilapangan maka didapat hasil bahwa suhu permukaan daratan hasil pengolahan citra dengan suhu permukaan dilapangan mempunyai korelasi sebesar 0,73 . Nilai tersebut berada pada interval 0,70-0,799. Sehingga dapat dinyatakan bahwa hasil pengolahan suhu permukaan daratan dari band 10 citra satelit Landsat 8 OLI/ TIRS memiliki hubungan yang kuat terhadap suhu permukaan daratan dilapangan. Sedangkan untuk band 11 berdasarkan 24 titik sampel yang diuji korelasinya antara suhu permukaan daratan hasil pengolahan citra dan suhu dilapangan maka didapat hasil bahwa suhu permukaan daratan hasil pengolahan citra dengan suhu permukaan dilapangan mempunyai korelasi sebesar 0,65 . Nilai tersebut berada pada interval 0,60-0,799. Sehingga dapat dinyatakan bahwa hasil pengolahan suhu permukaan daratan dari band 11 citra satelit Landsat 8 OLI/ TIRS memiliki hubungan yang kuat terhadap suhu permukaan daratan dilapangan.Hasil uji korelasi dapat dilihat pada (Gambar 7 dan 8).

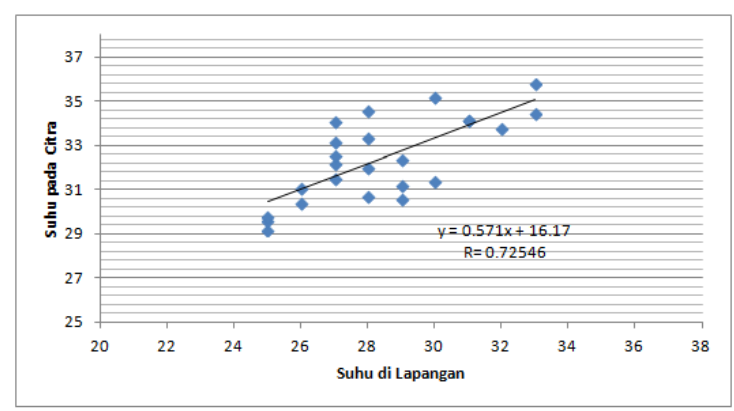

Gambar 7. Diagram Scatter Hasil Uji

Korelasi Antara Suhu Permukaan Daratan Dari Pengolahan Citra Dengan Pengukuran Di Lapangan Band 10

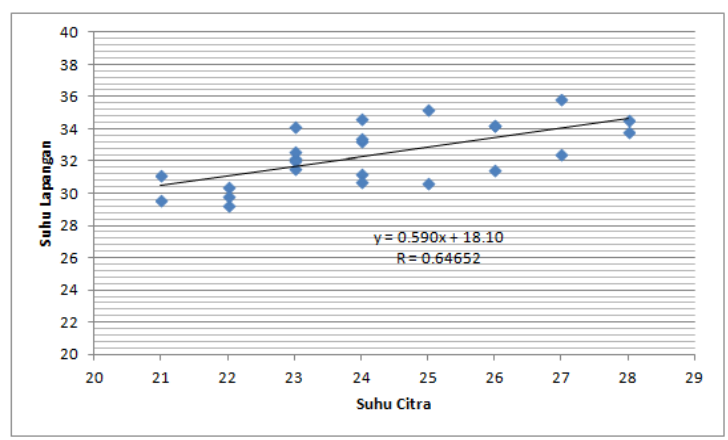

Gambar 8. Diagram Scatter Hasil Uji

Korelasi Antara Suhu Permukaan Daratan Dari Pengolahan Citra Dengan Pengukuran Di Lapangan Band 11

Meskipun nilai korelasi suhu pada band 11 menunjukkan hubungan yang kuat dengan suhu di lapangan, pada penelitian ini hanya akan digunakan hasil ekstraksi dari band 10. Hal ini karena nilai suhu 
permukaan daratan yang dihasilkan dari ekstrasi band 10 lebih mendekati suhu di lapangan dibandingkan dengan hasil ekstrasi pada band 11. Selain itu, beberapa literatur dan penelitian sebelumnya mengenai suhu permukaan daratan juga hanya menggunakan band 10 untuk mengidentifikasi suhu permukaan daratan. Hal ini dikarenakan ketelitian suhu yang dihasilkan oleh band 10 jauh lebih baik dibandingkan dengan band 11 atau secara teknis band 11 kurang memiliki akurasi yang tinggi dalam mengestimasi suhu permukaan daratan.

\subsection{Sebaran UHI di Kota kendari}

Studi pendahuluan terhadap kondisi suhu udara di Kota Kendari selama beberapa tahun terakhir menunjukkan tren peningkatan. Selain terjadi tren tersebut, suhu udara Kota Kendari juga lebih tinggi dari daerah sekitarnya. Tercatat suhu udara rata-rata di Kabupaten Konawe Selatan, pada tahun yang sama lebih rendah, yakni sebesar $27^{\circ} \mathrm{C}$ atau terjadi perbedaan suhu udara sebesar $1^{\circ} \mathrm{C}$. Hal ini sejalan dengan pernyataan mengenai fenomena UHI pada daerah perkotaan dimana suhu udara pada area kota akan lebih tinggi dibandingkan daerah- daerah di sekitarnya.

Banyak hal yang menjadi faktor semakin meningkatnya suhu udara dan suhu permukaan daratan di Kota Kendari, diantara jumlah polutan yang meningkat, kurangnya Ruang Terbuka Hijau untuk menetralisir suhu udara, serta perkembangan Kota yang cukup pesat yang juga menaikkan angka pembangunan dan menyebabkan banyaknya lahan hijau yang terkonversi menjadi kawasan industri dan kawasan perdagangan dan jasa serta kawasan permukiman. Weng Qihao dan Yang S (2006) menyatakan bahwa pola spasial polutan udara berkorelasi positif terhadap kepadatan bangunan kota dan suhu permukaan daratan yang berasal dari citra satelit. Band termal inframerah pada citra satelit dapat memainkan peran khusus dalam memonitoring dan pemodelan polusi udara. Selain itu penelitian terkait 38 --- April hubungan suhu permukaan daratan dengan polutan udara (Nitro Oksida dan Sulfur Oksida) di DKI Jakarta. Dan hasil penelitian menujukkan terdapat asosiasi keduanya. Jadi pencemaran udara yang tinggi dapat menyebabkan suhu permukaan daratan yang tinggi pula selain itu suhu permukaan daratan dapat dijadikan indikator adanya pencemaran udara disuatu wilayah..

Menurut data dari Badan pusat statistik Kota Kendari jumlah kendaraan roda dua atau sepeda motor pada tahun 2013 tercatat sebanyak 3.490 buah yang kemudian mengalami peningkatan pesat pada tahun 2017 menjadi 11.151 buah. Dalam kurun waktu tiga tahun jumlah kendaraan roda dua meningkat sebanyak 7.661buah atau sebesar $320 \%$ dari tahun 2013. Peningkatan jumlah kendaraan yang massive ini berkontribusi besar pada naiknya suhu permukaan daratan di Kota Kendari. Selain jumlah kendaraan yang meningkat, jumlah sarana perdagangan juga meningkat tercatat sebanyak 2.298 toko, 5.074 kios, dan 7.773 warung tercatat pada tahun 2016. Sedangkan pada tahun 2013 jumlah toko tercatat hanya 1.098 unit.

Suhu permukaan daratan juga dipengaruhi oleh tingkat kerapatan vegetasi pada suatu wilayah. Berdasarkan hasil analisis NDVI yang didapatkan, nilai kerapatan vegetasi di Kota Kendari berkisar -0,23 hingga 0,63. Dilihat dari persebarannya, daerah yang memiliki kerapatan vegetasi rendah atau daerah dengan nilai indeks vegetasi di bawah 0.32 adalah kawasan pemukiman, lahan kosong, serta kawasan perdagangan dan jasa. Selain itu hasil analisis juga menunjukkan daerah dengan indeks kerapatan vegetasi yang rendah adalah daerah-daerah dengan suhu permukaan daratan tertinggi di Kota Kendari. Contohnya kawasan Mall Mandonga suhu udara pada citra sebesar $33^{\circ} \mathrm{C}$ sedangkan nilai indeks kerapatan vegetasinya 0,01 . Untuk melihat kaitan suhu permukaan daratan dengan kerapatan vegetasi dan penggunaan lahannya, peneliti 
mengambil 15 titik pada hasil analisis NDVI. Hubungan kedua variabel dapat dilihat pada (Gambar 9).

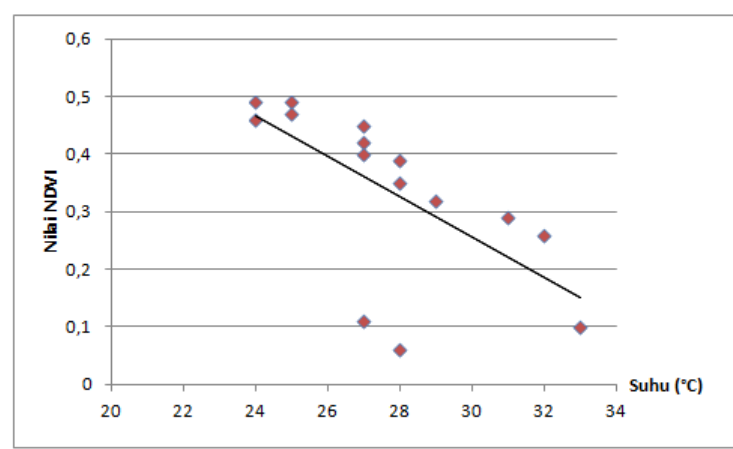

Gambar 9. Hubungan Suhu Pada Citra Dengan Nilai Indeks Kerapatan Vegetasi.

Nilai dari hasil analisis korelasi pada (Gambar 9) adalah -0.66 yang berarti semakin rendah nilai indeks vegetasinya, maka semakin tinggi suhu permukaan daratannya. Atau sebaran suhu permukaan berbanding terbalik dengan nilai sebaran kerapatan vegetasi. Hal ini diperkuat dengan penelitian dari Kumar (2012) yang melakukan estimasi suhu permukaan daratan di Kota Vijayawada, India dengan citra satelit Landsat. Hasil suhu permukaan daratan dihubungkan dengan nilai NDVI pada wilayah tersebut. Dari hasil tersebut didapat nilai sebesar -0.79 yang berarti bahwa semakin rendah nilai indeks vegetasi maka semakin tinggi nilai suhu permukaan daratannya.

Berdasarkan hasil analisis suhu permukaan daratan pengolahan citra Landsat 8 OLI/TIRS Kota Kendari perekaman tanggal 30 Agustus 2017 pukul 09.47 suhu permukaan daratan yang dihasilkan berkisar antara $15,27^{\circ} \mathrm{C}$ sampai dengan $33,34^{\circ} \mathrm{C}$. Suhu 15 sampai dengan $22^{\circ} \mathrm{C}$ adalah suhu daerah yang tertutup awan. Persebaran suhu didominasi suhu diantara $23-27^{\circ} \mathrm{C}$ seluas $21.492,46 \mathrm{Ha}$ atau $81.02 \%$ dari luas wilayah. Sedangkan daerah yang teridentifikasi sebagai daerah UHI dengan suhu diantara $28-33^{\circ} \mathrm{C}$ seluas $2.968,57 \mathrm{Ha}$ atau $11.01 \%$ dari luas wilayah Kota Kendari.
Daerah-daerah yang teridentifikasi sebagai daerah UHI atau daerah dengan suhu diatas $28^{\circ} \mathrm{C}$ umumnya adalah kawasan perdagangan dan jasa serta permukiman kerapatan tinggi yang tersebar di beberapa titik di seluruh kecamatan yang ada di Kota Kendari. Kecamatan Kadia dan Mandonga menjadi dua kecamatan dengan suhu permukaan daratan tertinggi terutama pada beberapa kelurahan seperti di kelurahan Mandonga, Korumba, Kadia, Podambae, Bende, Anawoi, dan Matawoi. Di Kecamatan Kendari juga terdapat beberapa titik dengan suhu diatas $32^{\circ} \mathrm{C}$ utamanya di kawasan industri seperti pada kawasan PT. Pertamina yang terdapat di kelurahan Kasilampe dan Kendari Caddi.

Ada beberapa hal yang memicu terjadinya UHI di perkotaan khususnya Kota Kendari. Salah satu diantaranya adalah kurangnya kawasan hijau atau Ruang Terbuka Hijau sebagai penetralisir suhu udara dan suhu permukaan daratan. Berdasarkan hasil analisis penggunaan lahan Kota Kendari menggunakan citra Google Earth dan data Ruang Terbuka Hijau dari Dinas Pekerjaan Umum Kota Kendari total luas Ruang Terbuka Hijau eksisting di Kota Kendari saat ini hanya $515.919 \mathrm{Ha}$ atau $1.98 \%$ dari luas Kota Kendari. Padahal apabila merujuk pada Peraturan Menteri Pekerjaan Umum Nomor 5 Tahun 2008 ukuran minimal Ruang Terbuka Hijau untuk menjamin keseimbangan ekosistem Kota adalah sebesar $30 \%$ dari total luas wilayah kota tersebut. Sehingga dapat disimpulkan bahwa di Kota Kendari masih sangat kekurangan Ruang Terbuka Hijau dan hal inilah yang menyebabkan terjadinya fenomena di Kota Kendari.

\section{KESIMPULAN}

Berdasarkan tujuan dan hasil penelitian, maka yang dapat disimpulkan dalam penelitian ini adalah suhu permukaan daratan hasil pengolahan citra Kota Kendari pada tanggal 30 Agustus 
2017 pukul 09.47 berkisar antara $15,27^{\circ} \mathrm{C}$ sampai dengan $33,34^{\circ} \mathrm{C}$. Suhu 15 sampai dengan $22^{\circ} \mathrm{C}$ adalah suhu daerah yang tertutup awan. Persebaran suhu didominasi suhu diantara $23-27^{\circ} \mathrm{C}$ seluas $21.492,46 \mathrm{Ha}$ atau $81.02 \%$ dari luas wilayah, dengan daerah yang teridentifikasi sebagai daerah UHI dengan suhu diantara $28-33^{\circ} \mathrm{C}$ seluas $2.968,57 \mathrm{Ha}$ atau $11.01 \%$ dari luas wilayah Kota Kendari.

Semakin tinggi persentase kerapatan vegetasi maka semakin rendah suhu permukaan daratannya sedangkan semakin tinggi persentase lahan terbangunnya maka semakin tinggi suhu permukaan daratannya. Korelasi suhu permukaan daratan hasil pengolahan citra dengan kondisi dilapangan adalah sebesar 0,73 (Kuat). Sehingga dapat disimpulkan bahwa estimasi suhu permukaan daratan dari band 10 citra satelit Landsat 8 OLI/TIRS dapat digunakan sebagai data utama untuk mendeteksi Urban Heat Island.

\section{DAFTAR PUSTAKA}

Badan Pusat Statistik Kota Kendari. 2017. Kota Kendari dalam Angka. Kendari: BPS

IPCC., 2007, The Fourth Assessment Report Climate Change, IPCC.

Kumar, K. Sundara. Bhaskar P. Udaya. Padmakumari K. 2012. Estimation Of Land Surface Temperature To Study Urban Heat Island Effect Using Landsat ETM+ Image. International Journal of Engineering Science and Technology (IJEST), Vol. 4 No.02

Lilesand, T., Kiefer, R.W., Chipman, J. 2007. Remote Sensing and Image Interpretation (Penginderaan Jauh dan Interpretasi Citra). John Wiley $\&$ Sons, Inc, U.S.A., $6^{\text {th }}$ ed., 804

Santi, Belinda, Sitti., Rianty, Hapsa. 2017. Identifikasi Potensi UHI terhadap RTH dan Kenyamanan Thermal pada Taman Walikota di Kota Kendari. Temu Ilmiah ILBI 2017.
Sugiyono, 2007. Statistika untuk Penelitian. Bandung: Penerbit Alfabeta.

Tursilowati, Laraz. 2012. Urban Heat Island dan Kontribusinya Pada Perubahan Iklim dan Hubungannya dengan Perubahan Lahan. LAPAN: Pusat Pemanfaatan Sains Atmosfer dan Iklim.

Weng, Qihao \& Yang S. 2006. Urban Air Pollution Patterns, Land Use, and Thermal Landscape: An Examination Of The Linkage Using GIS. Environmental Monitoring and Assessment, Vol. 117, No.4, pp.463489,

40 --- April 